\title{
UPAYA MENINGKATKAN HASIL BELAJARDENGAN MENGGUNAKAN PEMBELAJARAN KOOPERATIF TIPE TGT MATERI PEWARISAN SIFAT PADA MAHLUK HIDUP KELAS IX- 6 SMP NEGERI 4 KOTA TERNATE
}

\author{
Amina Puradin ${ }^{1}$ Said Hasan ${ }^{2}$ A.R Tolangara ${ }^{3}$ \\ ${ }^{123}$ Program Magister Pendidikan Biologi Universitas Khairun Ternate
}

\begin{abstract}
Abstrak
Penelitian ini bertujuan untuk meningkatkan hasil belajar dengan menggunakan model pembelajaran team games tournament kelas $\mathrm{IX}_{6}$ SMP Negeri 4 Kota Ternate tahun pelajaran 2018- 2019 pada materi pewarisan sifat pada mahluk hidup, Penelitian dilaksanakan pada bulan September 2018. Jenis penelitian yakni desain penilitian tindakan kelas ( PTK) dengan menggunakan dua siklus. Hasil Penelitian menunjukkan Penerapan Model pembelajaran kooperatif tipe TGT pada mata pelajara IPA materi Pewarisan sifat pada Mahluk hidup kelas IX 6 SMP Negeri 4 Kota Ternate dapat meningkatkan hasil belajar siswa. Hal ini terlihat bahwa prestasi belajar siswa kelas $\mathrm{IX}_{6}$ pada tes awal nilai rata-rata $40,27 \%$ ketuntasan. Sedangkan pada post test 1 nilai rata-rata 60.04 dan peningkatan hasil belajar sebesar $23 \%$ dengan gain score 0.46 kategori sedang. Pada post test 2 nilai rata-rata siswa 82.09 , ketuntasan $95 \%$ dan peningkatan hasil belajar sebesar $45 \%$ dengan gain score 1.23 kategori tinggi.
\end{abstract}

Kata kunci: TGT, Hasil Belajar, Pewarisan Sifat Pada Mahluk Hidup

\section{PENDAHULUAN}

Pendidikan merupakan kebutuhan utama yang harus dimiliki oleh setiap manusia agar dapat meningkatkan dan mengembangkan kualitas sumber daya manusia (SDM). Pendidikan juga dapat menentukan kemajuan suatu bangsa dan dapat mengubah siswa kearah yang lebih baik. Banyak perhatian khusus di arahkah kepada perkembangan dan kemajuan dunia pendidikan (Isjoni, 2009 ). Berbagai upaya telah dilakukan pemerintah dalam rangka meningkatkan mutu dan kualitas pendidikan di Indonesia, salah satunya adalah dengan melakukan pengembangan kurikulum dengan salah satu tujuan meningkatkan hasil belajar siswa.

Hasil belajar merupakan perubahan perilaku secara menyeluruh yang ditandai adanya kemampuan-kemampuan yang dimiliki oleh siswa setelah menerima pengalaman belajarnya, hasil belajar mencerminkan nilai yang dicapai seseorang dari ranah kognitif, afektif, maupun ranah psikomotor (Sudjana, 2009). Hasil belajar seringkali digunakan sebagai ukuran untuk mengetahui seberapa jauh seseorang menguasai bahan yang diajarkan (Purwanto, 2014).Hasil belajar juga merupakan kemampuan yang telah dicapai oleh seseorang setelah melakukan kegiatan 
belajar, yang menghasilkan perubahan kearah yang lebih baik pada diri seseorang, baik dalam hal pengetahuan, pemahaman maupun sikap (Zulkifli, 2010).

Keberhasilan belajar siswa dalam penguasan materi pelajaran salah satunya dipengaruhi dari kemampuan guru dalam memilih dan menggunakan model yang disesuaikan dengan materi yang diajarkan, sehingga siswa dapat berperan secara aktif mengembangkan minat dan kemampuan yang dimilikinya,dengan demikian pembelajaran tidak hanya berpusat pada guru.dalam hal ini guru hanya sebagai fasilitator sekaligus sebagai pembimbing bagi siswa yang mengalami kesulitan di dalam proses pembelajaran. Solihatin dan Raharjo, (2008:4) mengatakan bahwa pembelajaran kooperatif merupakan suatu sikap atau perilaku bersama dalam bekerja dalam struktur kerja yang sangat dipengaruhi oleh keterlibatan dari setiap anggota kelompok itu sendiri

Nurulwati (2000) mengatakan bahwamodel pembelajaran adalah kerangka konseptual yang melukiskan prosedur yang sistematis dalam mengorganisasikan pengalaman belajar untuk mencapai tujuan belajar tertentu, dan berfungsi sebagai pedoman bagi paraperancang pembelajaran dan parapengajar dalam merencanakan aktivitas belajar mengajar. Pembelajaran kooperatif tipe Team Games Tournament (TGT) merupakan salah satu pembelajaran kooperatif yang mudah diterapkan, karena melibatkan aktifitas seluruh siswa tanpa harus ada perbedaan status, melibatkan peran siswa sebagai tutor sebaya dan mengandung unsur permainan sehingga dapat memotivasi siswa dalam proses pembelajaran IPA.

Pembelajaran kooperatif tipe TGT merupakan salah satu tipe pembelajaran kooperatif yang mudah diterapkan, melibatkan aktifitas seluruh siswa tanpa harus ada perbedaan status, melibatkan peran siswa sebagai tutor sebaya dan mengandung unsur permainan (Shoimin, 2014). TGT juga merupakan model pembelajaran yang dapat memotivasi siswa karena TGT merupakan model pembelajaran yang menyenangkan dan melibatkan aktivitas seluruh siswa (Slavin 2008).

Rohjianti,(2012) menyatakan bahwa dengan model pembelajaran kooperatif tipe (TGT) dengan materi gerak pada tumbuhan yang dilakukan pada siswa dikelas VIII SMP Negeri 2 kradenan tahun ajaran 2011/2012 menggunakan model TGT dengam media ular tangga ternyata dapat meningkatkan hasil belajar siswa aspek kogntif pada siklus I adalah 39,47\% dan pada siklus II adalah 76,31\% sedangkan aspek efektif observasi awal 15,78\% meningkat menjadi 67,06 \% dengan kategori cukup, meningkat menjadi $85,65 \%$ berkategori tinggi.

Berdasarkan observasi yang dilakukan di Smp Negeri 4 Kota ternate terhadap guru mata pelajaran IPA, bahwa dalam kegiatan belajar mengajar ditemukan banyak siswa yang sulit menyerap pembelajaran yang diajarkan oleh 
guru, karena guru kurang memanfaatkan model pembelajaran dalam proses pembelajaran IPA dan materi yang diajarkan di kelas masih menggunakan metode ceramah. Hal ini menyebabkan siswa tidak aktif karena hanya mendengarkan, mencatat membuat siswa menjadi tidak terantusiasi memperhatikan materi yang sedang diajarkan oleh guru, siswa minim aktifitas dan pemahaman daya serap siswa terhadap materi IPA masih kurang, sehingga hasil belajar siswa rendah, salah satunya pada materi pewarisan sifat pada mahluk hidup membuat siswa tidak aktif dalam proses pembelajaran sehingga rata-rata nilai siswa pada mata pelajaran IPA di SMP Negeri 4 Kota Ternate masih dibawa standar ketuntasan mimimal (KKM) yaitu dibawa nilai 75 .

Tujuan penelitian ini meningkatkan hasil belajar dengan menggunakan model pembelajaran (TGT) kelas IX-6 SMP Negeri 4 Kota Ternate tahun pelajaran 2018-2019 pada materi pewarisan sifat pada mahluk hidup.

\section{METODE PENELITIAN}

Jenis penelitian yang digunakan dalam penelitian tindakan kelas (Classroom Action Research). Penelitian tindakan kelas adalah penelitian tindakan yang dilakukan di kelas dengan tujuan memperbaiki atau meningkatkan mutu pembelajaran (Arikunto, dkk. 2008). Penelitian tindakan kelas merupakan suatu pencermatan terhadap kegiatan yang sengaja dimunculkan, dan terjadi dalam sebuah kelas (Aqib, 2006), pelaksanaan tindakan kelas dapat dibagi menjadi 4 tahap 1) perencanaan 2) melakukan tindakan 3) melaksanakan pengamatan 4) mengadakan refleksi. Dalam penelitian ini peneliti menggunakan model pembelajaran kooperatif tipe TGT untuk mengetahui peningkatan hasil belajar dengan materi Pewarisan sifat pada mahluk hidup. Penelitian ini dilaksanakan selama satu bulan yaitu bulan September 2018. Adapun sampel yang digunakan pada kelas $\mathrm{IX}_{6}$ yang berjumlah 22 siswa terdiri dari 11 siswa laki-laki dan 11 peserts didik perempuan. Data pada penelitian ini diperoleh dengan menggunakan instrumen test uraian yang berjumlah 10 butir soal, soal tersebut diberikan pada saat pre test dan post test guna menjaring data pada ranah kognitif. Tujuan dari pemberian pre test dan post test adalah untuk mengetahui peningkatan hasil belajar siswa sebelum dan sesudah pembelajaran. Analisis data dalam penelitian ini menggunakan uji persentase dengan rumus berikut: 


$$
\begin{gathered}
R \\
S=----\mathrm{X} 100 \% \\
N
\end{gathered}
$$

Keterangan:

$$
\begin{array}{ll}
\mathrm{S} & \text { : Nilai yang dicari/diharapkan } \\
\mathrm{R} & \text { : Jumlah skor dan item/soal yang dijawab benar } \\
\mathrm{N} & \text { : Skor maksimal ideal dari tes tersebut } \\
100 & \text { : Bilangan tetap (Purwanto, 2004) }
\end{array}
$$

Selanjutnya Hedayati dkk (2017) menyatakan hasil tes berupa pretest dan posttest dianalisis dengan rumus gain skor sebagai berikut:

$$
\mathrm{g}=\frac{\text { skor posttest-pretest }}{\text { skor maksimum-pretest }}
$$

Kemudian untuk hasil analisis ditentukan dengan tabel kriteria gain score menurut Hake (1999) adalah sebagai berikut.

Tabel 1. Kriteria gain score

\begin{tabular}{|c|c|}
\hline Gain Score & Kriteria \\
\hline$g \geq 0,7$ & Tinggi \\
\hline $0,3 \leq g<0,7$ & Sedang \\
\hline$g<0,3$ & Rendah \\
\hline
\end{tabular}

\section{HASIL DAN PEMBAHASAN}

\section{Hasil}

Hasil penelitian yang diperoleh pada pre test, post test 1 dan post test 2 yang telah dilaksanakan dengan kriteria ketuntasan minimum yang ditetapkan oleh SMP Negeri 4 Kota Ternate yaitu kkm sebesar 75. Hasil penelitian meliputi jenis tes, nilai rata-rata, ketuntasan, peningkatan hasil belajar, gain score dan kriteria. Hasil penelitian tersebut disajikan pada tabel 2 berikut ini.

Tabel 2. Peningkatan Prestasi Belajar Siswa kelas IX 6 SMP Negeri 4 Kota Ternate

\begin{tabular}{|l|c|c|c|c|c|}
\hline Jenis tes & Nilai rata-rata & $\begin{array}{c}\text { Ketuntasan } \\
(\%)\end{array}$ & $\begin{array}{c}\text { Peningkatan } \\
\text { Hasil Belajar }\end{array}$ & Gain Score & Kategori \\
\hline Pre test & 40 & 27 & & & \\
\hline Post test 1 & 60.04 & 50 & $23 \%$ & 0.46 & Sedang \\
\hline Post test 2 & 82.09 & 95 & $45 \%$ & 1.23 & Tinggi \\
\hline
\end{tabular}


Dari hasil pre test tersebut dapat diketahui bahwa persentase siswa yang mencapai nilai ketuntasan hanya 6 orang dari 22 siswa dengan persentase $27 \%$. Hal ini membuktikan bahwa persentase siswa kelas $\mathrm{IX}_{6}$ pada materi pewarisan sifat pada mahluk hidup tergolong masih rendah. Hasil pre test ini selanjutnya akan digunakan peneliti sebagai acuhan pada post test 1 dan post test 2.

Tabel 2 menunjukkan bahwa prestasi belajar siswa kelas $\mathrm{IX}_{6}$ pada pre test nilai rata-rata 40 dengan ketuntasan $27 \%$. Sedangkan pada post test 1 nilai rata-rata 60.04 dan peningkatan hasil belajar sebesar $23 \%$ dengan gain score 0.46 kategori sedang. Kemudian pada post test 2 nilai rata-rata siswa 82.09 dengan ketuntasan 95\% dan peningkatan hasil belajar sebesar $45 \%$ dengan gain score 1.23 kategori tinggi.

\section{b. Pembahasan}

Hasil penelitian menunjukkan bahwa pada pre test belum ada peningkatan. Setelah menggunakan model pembelajaran kooperatif TGT maka terjadi peningkatan pada post test I siklus I dengan ketuntasan siswa sebesar 50\% (11 siswa belum tuntas) dan peningkatan sebesar 23\%. Hal ini sejalan dengan Hasanah dan Rahman (2017) dalam hasil penelitiannya, hasil belajar model pembelajaran yang digunakan sebelum siklus 1 kurang maksimal sehingga hasil belajar siswa masih rendah. Kemudian, pada siklus I terjadi peningkatan penggunaan Model pembelajaran kooperatif tipe TGT dengan tutor sebaya diperoleh nilai rata-rata prestasi belajar siswa adalah 62,5 dan ketuntasan belajar mencapai $50 \%$ atau ada 16 siswa dari 32 siswa sudah tuntas belajar. Sejalan dengan Hedayati dkk (2017) yang hasil penelitiannya menyatakan bahwa model pembelajaran TGT dengan menggunakan media Puzzle dapat meningkatkan motivasi dan hasil belajar IPA pada SMP Negeri 2 Tempel kelas VIII dilihat dari aspek kognitif atau siswa mencapai KKM 75 pada post test 1 dengan kriteria tuntas sebesar $50 \%$.

Hasil uji gain score pada post test siklus I yaitu 0.46 berkategori sedang. Hal ini sejalan dengan Hake (1999) yang menyatakan bahwa gain score $0,3 \leq g<0,7$ berkategori sedang. Yudianto dkk (2014) dalam hasil penelitian penerapan model pembelajaran tipe kooperatif TGT menyatakan bahwa pada siklus I hasil uji gain score sebesar 0.46 dengan kategori sedang.

Hasil yang diperoleh pada post test siklus II terjadi peningkatan dibandingkan dengan siklus I. Ketuntasan hasil belajar siswa sesuai dengan KKM IPA yaitusebesar 95\% (21 siswa tuntas) dan mengalami peningkatan sebesar $45 \%$. Hal ini sejalan dengan hasil penelitian Hasanah dan Rahman (2017) bahwa terjadi peningkatan hasil belajar siswa menggunakan model pembelajaran TGT post test 
(tes akhir) ketuntasan belajar sebesar 90\% dengan nilai rata-rata 83,8. Maka dapat dikatakan bahwa ketuntasan belajar siswa dibanding dengan pretest jauh lebih bagus. Putri dkk (2003) dalam hasil penelitiannya pada siklus II terjadi peningkatan dengan hasil belajar kognitif sebesar $82.61 \%$ dan mengalami peningkatan sebesar 30.44\%. Sejalan dengan hasil penelitian Respati dkk (2013) dalam penerapan model pembelajaran TGT pada siklus II menunjukkan bahwa keaktifan siswa dalam mengikuti kegiatan pembelajaran naik $85 \%$, keaktifan siswa dalam berperan kelompok naik $80 \%$, dan prestasi belajar siswa naik $95 \%$. Hasil uji gain score pada post test siklus II yaitu sebesar 1.23 berkategori tinggi. Hal ini sejalan dengan Hake (1999), Mchunu \& Imenda (2015) menyatakan bahwa gain score $0,3 \leq g<0,7$ berkategori tinggi.

Menurut Mulyasa (2003), pembelajaran dikatakan berhasil dan berkualitas apabila seluruhnya atau setidaknya sebagian besar (75\%) siswa terlibat secara aktif, baik fisik, mental maupun sosial dalam proses pembelajaran dan memiliki rasa percaya diri yang tinggi. Sedangkan dari segi hasil proses pembelajaran dikatakan berhasil apabila terjadi perubahan perilaku yang positif dari siswa seluruhnya atau setidak-tidaknya sebagian besar (75\%).

Model pembelajaran kooperatif tipe TGT dapat meningkatkan hasil belajar siswa. Hal ini sesuai dengan penelitian yang dilakukan oleh Zulaikha (2014), yang menyatakan bahwa hasil belajar siswa mengalami peningkatan yang signifikan dengan menerapkan model pembelajaran kooperatif tipe TGT pada materi wujud zat. Penelitian yang dilakukan oleh Tanjung (2017) juga menyatakan bahwa pada kompetensi pengetahuan atau hasil belajar siswa meningkat dengan menerapkan strategi pembelajaran TGT.

Peningkatan hasil belajar dapat disebabkan karena siswa tertarik dalam pembelajaran model kooperatif tipe TGT. Hasil respons siswa terhadap pelaksanaan pembelajaran menggunakan model kooperatif tipe TGT menunjukkan hal yang sama yakni siswa merespons secara positif terhadap proses pembelajaran model kooperatif tipe TGT. Respons positif siswa dikarenakan siswa merasa senang dalam proses pembelajaran. Pendapat ini didukung oleh penelitian Iasha (2013) yang menyatakan bahwa model kooperatif tipe TGT sangat menyenangkan karena selain belajar mereka juga turut dalam permainan akademik dengan situasi yang menyenangkan. Handayani (2010) mengatakan bahwa aktifitas belajar dengan permainan yang dirancang dalam pembelajaran kooperatif tipe TGT memungkinkan siswa lebih rileks dalam belajar, selain menumbuhkan tanggung jawab, kerjasama, persaingan sehat, dan keterlibatan siswa. Rohwati (2012) menambahkan dengan menggunakan education game dalam pembelajaran dapat 
meningkatkan hasil belajar, keaktifan siswa, penguasaan bahasa serta penggunaan ICT.

\section{SIMPULAN}

Berdasarkan uraian penelitian, maka dapat disimpulkan bahwa penerapan model pembelajaran kooperatif tipe TGT pada mata pelajara IPA materi pewarisan sifat pada mahluk hidup kelas IX6 SMP Negeri 4 Kota Ternate dapat meningkatkan hasil belajar siswa. Hal ini terlihat bahwa prestasi belajar siswa kelas $\mathrm{IX}_{6}$ pada pre test nilai rata-rata 40 , ketuntasan sebesar $27 \%$. Sedangkan pada post test 1 nilai rata-rata 60.04 dan peningkatan hasil belajar sebesar $23 \%$ dengan gain score 0.46 kategori sedang. Pada post test 2 nilai rata-rata siswa 82.09, ketuntasan $95 \%$ dan peningkatan hasil belajar sebesar $45 \%$ dengan gain score 1.23 kategori tinggi.

\section{DAFTAR PUSTAKA}

Arikunto, Suharsimi., dkk. 2008. Penelitian Tindakan Kelas. Jakarta: Bumi Aksara Isjoni. 2009. Cooperative Learning (Efektivitas Pembelajaran Kelompok). Bandung : Alfabeta.

Aqib, Zainal. 2006. Penelitian Tindakan Kelas. Bandung: Yrama Widya.

Hake, Richard R. 1999. Analyzing Change/Gain Scores. Diakses tanggal 11 Januari 2019 http://www.physics.indiana.edu/ sdi/AnalyzingChangeGain.pdf.

Handayani, F. 2010. Pembelajaran Kooperatif Tipe TGT (TGT) untuk Meningkatkan Hasil Belajar Siswa Kelas VII SMP Negeri 1 Purwodadi Kabupaten Pasuruan pada Materi Keragaman Bentuk Muka Bumi. Jurnal Penelitian Pendidikan, Th. 20, No. 2, Oktober 2010

Hasanah, M. Rahman, K. 2017. Penerapan Model Pembelajaran Kooperatif Tipe Tgt (Team Game Tournament) Dengan Metode Tutor Sebaya Untuk Menuntaskan Hasil Belajar Siswa Pada Kelas X Ipa 6 Sman 2 Pamekasan. Momentum: Physics Education Journal. Vol 1, No 1, (2017) 66-82.

Hedayati, H., Suyoso., Anjarsari, P. 2012. Upaya Peningkatan Motivasi Dan Hasil Belajar Kognitif IPA Siswa Kelas VIII E SMP Negeri 2 Tempel Melalui Pembelajaran Cooperative Learning Tipe TGT (TGT) Dengan Media Puzzle. Jurnal Pendidikan Matematika dan Sains.

Iasha, R.R. 2013. Penerapan Pembelajaran IPA Terpadu menggunakan Model Pembelajaran Kooperatif Tipe Teams Games Turnaments (TGT) pada Tema Pemanasan Global terhadap Hasil Belajar Siswa Kelas VII SMP. Skripsi. 
Tidak dipublikasikan. Surabaya: Fakultas Matematika dan Ilmu Pengetahuan Alam.

Kurniaty, D.F. Haryono, T. Nurita T. Penerapan Model Kooperatif Tipe TGT Terhadap Aspek Pengetahuan Dan Keterampilan Siswa Kelas VIII. E-Jurnal Pensa. Volume 05 Nomor 02 54-59.

Mchunu, S. P., \& Imenda, S. N. 2015. The Effects of Traditional, Outcomes Based Education (OBE) and Blended Teaching Approaches in Alleviating Conceptual Difficulties and Alternative Conceptions in Grade Twelve Mechanics. Conception Sciences, 8(2), 333-343.

Mulyasa. E. 2003. Kurikulum Berbasis Kompetens;Konsep, Karakteristik dan Implementasi. PT Remaja Rosda Karya. Bandung.

Nurulwati. 2000. Model-model Pembelajaran. Surabaya: Universitas Negeri Surabaya.

Purwanto, Ngalim. 2004. Prinsip-Prinsip dan Teknik Evaluasi Pengajaran. Bandung : Rosdakarya.

Purwanto. 2014. Evaluasi Hasil Belajar. Yogyakarta: Pustaka Pelajar

Putri, P.S. Martini, S.K. Nurhayati, D.N. 2013. Penerapan Metode Pembelajaran Teams Games Tournaments (Tgt) Dilengkapi Kartu Destinasi Untuk Meningkatkan Minat Dan Prestasi Belajar Pada Materi Minyak Bumi Siswa Kelas X 5 SMA Negeri Gondangrejo Tahun Pelajaran 2012 /2013. Jurnal Pendidikan Kimia (JPK), Vol. 2 No.4.

Respati, D, A., Adi, W., Muhtar. 2013. Penerapan Model Pembelajaran Kooperatif Tipe TGT Untuk Meningkatkan Prestasi Belajar Akuntansi. Jupe UNS, Vol 1, No 2.

Rohjianti, Jehat. 2012. Penerapan Metode Pembelajaran Teams Game Tournament (Tgt) Dengan Media Ular Tangga Dalam Pembelajaran Biologi Pokok Bahasan Gerak Pada Tumbuhan Untuk Meningkatkan Hasil Belajar Siswa. Naskah Publikasi. Universitas Muhammadiyah Surakarta.

Rohwati, M. 2012. Penggunaan Education Game untuk Meningkatkan Hasil Belajar IPA Biologi Konsep Klasifikasi Makhluk Hidup. Jurnal Pendidikan IPA Indonesia vol 1 (1) hal 75-81

Shoimin, Aris. 2014. 68 Model Pembelajaran INOVATIF dalam Kurikulum 2013. Yogyakarta: AR-RUZZ MEDIA

Solihatin, Etin dan Raharjo. 2008. Cooperatif Learning (Analisis Model Pembelajaran IPS). Jakarta : Bumi Aksara.

Slavin, R. 2008. Cooperative Learning: Theory, Research, and Practice. (Lita. Terjemahan). London: Allyn and Bacon.

Tanjung, N. 2017. Strategi Pembelajaran TGT (TGT) untuk Meningkatkan Hasil Belajar Siswa pada Materi Struktur dan Fungsi Jaringan Tumbuhan. Jurnal Online. http: //ejournal.unesa.ac.id/index.php/pensa/article /view/18506/baca-artikel. diakses pada 30 Januari 2019 
Zulkifli. 2010. Pengaruh Media Komik Terhadap Hasil Belajar Kimia Siswa Pada Konsep Reaksi Redoks. Skripsi diterbitkan. Jakarta: Program Studi Pendidikan Kimia UIN Syarif Hidayatullah.

Sudjana, Nana. 2009. Penilaian Hasil Proses Belajar Mengajar. Bandung:PT. Remaja Rosdakarya.

Zulaikha, N.F. 2014. Penerapan Model Pembelajaran Kooperatif Tipe TGTs (TGT) menggunakan Permainan Ball dan Card terhadap Hasil Belajar Siswa pada Materi Wujud Zat. Skripsi. Tidak dipublikasikan. Surabaya: Fakultas Matematika dan Ilmu Pengetahuan Alam. 